\title{
One body, one test, two lives.. patient centered strategy to increase HIV testing in pregnant women and their partners
}

\author{
Larisa Kudryashova-Hernandez \\ From 17th International Symposium on HIV and Emerging Infectious Diseases (ISHEID) \\ Marseille, France. 23-25 May 2012
}

\section{Background}

NHSC, an urban community-based health center in New Jersey, USA, provides prenatal services, labor/ delivery to 750 uninsured/impoverished/minority women annually. Given that NJ has the third highest number of HIV women in USA and the highest number of HIV children, early HIV detection/ intervention in pregnant women become paramount. NHSC historically struggled with sub-optimal OB HIV testing rates $(60 \%)$ and needed to make radical program changes to comply with CDC recommendations to ensure HIV testing is offered to $100 \%$ pregnant patients.

\section{Methods}

PDSA (Plan-Do-Study-Act) was conducted to test a new HIV testing approach: HIV Counselors are located in OB department; HIV counseling/ Rapid testing is done at $\mathrm{OB}$ registration; daily registration schedules are available to HIV Counselors; HIV results become part of OB records upon result availability; educational DVDs are utilized in patient areas to increase awareness/ interest.

\section{Results}

Per PDSA-improved strategy, NHSC sustained 100\% compliance with CDC recommendations over the last three years. Rapid HIV testing and Rapid-on-Rapid positive result confirmation allow for smooth/timely transition from HIV testing to care/treatment for newly diagnosed HIV pregnant patients/partners.

\section{Conclusions}

The collected/analyzed data suggests that coordinated, patient-centered approach helps to: identify HIV positive pregnant patients in the first/second trimesters; immediately connect them to prenatal/HIV care to minimize vertical HIV transmission; provide prevention/treatment for partners including prevention for positives.

Published: 25 May 2012

doi:10.1186/1742-4690-9-S1-P70

Cite this article as: Kudryashova-Hernandez: One body, one test, two lives.. patient centered strategy to increase HIV testing in pregnant women and their partners. Retrovirology 2012 9(Suppl 1):P70.

Submit your next manuscript to BioMed Central and take full advantage of:

- Convenient online submission

- Thorough peer review

- No space constraints or color figure charges

- Immediate publication on acceptance

- Inclusion in PubMed, CAS, Scopus and Google Scholar

- Research which is freely available for redistribution

Submit your manuscript at www.biomedcentral.com/submit

\section{() Biomed Central}

